\title{
SURVEY RESULTS ON MILITARY LEADER'S ABILITIES TO CREATE GENDER-SENSITIVE ENVIRONMENT
}

\section{Olena Volobuieva}

\section{INTRODUCTION}

Whenever we speak about the gender equality we have to remember that it is considered to be an index of democratic society. Ukraine is in the period of the education sector reforming now and this period is characterized by promoting gender equality as one of the principle facts of successful country development in order to achieve the Sustainable Development Goals by $2030^{1}$.

In this connection we would like to stress that the leader's ability to create gender-sensitive environment for proper development of any organization is an indisputable factor, and much more in the process of the nature of organizational life and management of social group as organized system including the military ones. The knowledge of these aspects will give a leader the opportunity to regulate group processes and influence upon group dynamics for its effective organization and development on the grounds of social-psychological determinants of group influence upon individuals ${ }^{2}$ taking into consideration the.

Having analyzed the term 'gender training' we would like to point out that it is not only the activity aimed at forming and developing the certain skills and habits in order to carry out professional duties up to the level. But the leader has to be able to influence the individual's consciousness, to increase awareness, knowledge and practical skills and habits on gender issues by sharing information, experiences and techniques.

${ }^{1}$ The Sustainable Development Goals by 2030. Retrieved from https:// www.un.org/sustainabledevelopment/blog/tag/security-council/.Agenda2030.pdf.

${ }^{2}$ Volobuieva Olena (2018). Social group as organized system: psychological aspect. Mizhnarodny naukovyi zhurnal «Osvita i nauka»// red. kol. : T. D. Shcherban (hol. red.). Mukachevo-Chenstokhova: RVVMDU; ta Akademiia im. Yana Dluhosha. 2(25). [in Ukrainian] 
The leader's abilities to create gender-sensitive environment is absolutely important because it is considered to be the essential part of military leader's gender competence, especially, and we would like to stress this fact, in the process of carrying out the professional duties, namely in problem-solving. In this connection we want to emphasize that the democratic development of Ukrainian society urgently requires updating, making positive changes to the organizational culture of higher education military education, taking into account the requirements of the current legislation as for equality among the whole personnel $^{3}$.

The issue of improving the organizational culture of the gendersensitive environment in the context of a higher military educational establishment is extremely relevant nowadays. It is crucial for leaders at all levels to understand gender issues and to be able to analyze the relationships between male and female subordinates.

To find out the level of awareness and correct understanding of the gender component to the leadership management of the head of the military unit and awareness of the components of the organizational (institutional, corporate) culture of an officer in charge of the security and defense sector and to determine the further effective vectors to increase the level of formation of their gender competence the system of professional training of the State Border Guard Service of Ukraine (the ability to create favorable conditions in the unit taking in account 16 sign soft sensitivity to gender issues ${ }^{4}$ for the effective performance of professional task sand prevention of human rights violations of both women and men, a survey of the leaders fall the level soft he National Academy of the State Border Guard Service of Ukraine named after Bohdan Khmelnitskyi (NASBGSU) was conducted.

3 Beijing Declaration and Platform for Action and UN Resolution 1325, UN goals for the $3^{\text {rd }}$ Millennium that emphasized promoting gender equality and empowering women as priority goals. UN's Millenium Goals.

${ }^{4}$ Raj, A, Stuart, R. and Kelleher, D. What is gender at Work's Approach to Gender Equality and Institutional. Retrieved from https://www.genderatwork.org/sites/genderatwork.org/files/resources/Gender_at_Work s_Approach.pdf. 


\section{Military leader's abilities to create gender-sensitive environment as part of professional competence}

In the investigation we have taken into our consideration the fact that the type of the dominant organizational culture influences the way its members behave with each other, the relationships set between superior and subordinates, the atmosphere surrounding the organization ${ }^{5}$.

It goes without saying the organizational culture has to be based on diversity management and gender equality ${ }^{6}$.

The questionnaire for assessing the awareness of leveldetermination was worked out taking into our account the recommendations for conducting a survey of the heads of all security sector institutions, as suggested in the Megan Bestik Handbook on Gender Self-Assessment for the Police, Armed Forces and the Justice Sector?.

The experience of the author of the study within the State Border Guard Service of Ukraine, the results of observations, interviews with the heads of the structural units, monitoring the performance of their duties, the results of the analysis of the feedback concerning the graduates of NAS

BSU indicate that the leader's ability to create a gender-sensitive environment (the necessary level of organizational culture institutional, cooperative culture) has been essential for the successful implementation of the management activities of border guard officers.

5 Felicia Cornelia Macarie, CălinHințea,Cristina Mora.Gender and leadership.The impact on organizational culture of public institutions. Transylvanian Review of Administrative Sciences, No. 32 E/2011, pp. 146-156. Retrieved from https://www.researchgate.net/publication/292452492_Gender_and_Leadership_The_I mpact_of_Organizational_Culture_of_Public_Institutions.

${ }^{6}$ Stephanie Ernst (2013). Theorizing and Practizing Organizational Culture and Diversity. A Case Study //AnnoIII, Numero 6/Dicembre Retrieved from https://www.accaglobal.com/content/dam/acca/global/PDF-technical/humancapital/pol-tp-tbcfdm-diversity-management.pdf.

${ }^{7}$ Women, Peace and Security (2011). Geneva. 


\section{Empirical study}

The empirical study was carried out on the basis of the psychological knowledge of the abilities of heads of the structural units of the SBGSU taking into account the real conditions of the educational establishment.

One of the methods of our study is the conducting the survey of the structural units leaders regarding the understanding and assessment of their abilities to create gender sensitive environment; their significance and structure within the professional competence of the up-to-day leader of the security and defense sector.

The investigation of the leaders' opinions by asking them 21 questions was aimed at determining their awareness level as for the gender perspective in the military environment in the subordinate units as the principle factor which determines the effectiveness of group dynamics based on the importance of diversity management ${ }^{8}$. In the investigation we have taken into our consideration the fact that for creating positive atmosphere on the grounds of realizing the fact that only gender professionally competent leader (who has a number of the important qualities required for the successful management of the subordinate personnel in the military environment, including the significance of gender equality and women's empowerment for the security sector reform) is capable of managing the personnel and carrying out the moral and psychological support effectively within the framework of promoting equal opportunities for both female and male subordinates.

For conceptual clarity it is essential to mention that while analyzing the very nature of the leadership context we paid our attention to the fact that commitment, complexity, and credibility are typical of the leadership environment and the fact that the most important is learning which is called and it is important not just to learn but how to learn in an organizational context. The real leaders are able to concentrate on what matters most to the organization and to use the organization as a learning environment.

${ }^{8}$ Stephanie Ernst 2013. Theorizing and Practicing Organizational Culture and Diversity. A Case Study // Anno III, Numero 6/Dicembre. Retrieved from https://www.accaglobal.com/content/dam/acca/global/PDF-technical/humancapital/pol-tp-tbcfdm-diversity-management.pdf). 
Having analyzed the real state of the male attitude towards female leaders in the security sector we have come to the conclusion that it is essential to teach leaders gender. And in this connection we would like to emphasize that nowadays in spite of the fact that the personnel can use a lot of the training manuals on gender and security, attend the various gender-oriented trainings and seminars there is the need to form so-called proper gender ideology ${ }^{9}$.

On the first phase of our investigation in order to determine the level of the organizational skills of the leaders of the structural units of the NASBSU to create gender-sensitive environment two expert groups were formed.

The experts were selected according to the following basic requirements (their professional competence, interest, efficiency, objectivity). We have taken into account that: 1) the components of the expert's competence are the essential part of the professional competence that extends to the object of study and qualitative (expert) competence, which requires the expert's knowledge of expert solution methodology of the research problem (for example, the participation in the socio-psychological research); 2) an expert has to have the interest in the results of the expertise generally depends on expert knowledge and skill of the investigation subject, a positive attitude towards it and the expert's problem-solving ability using the non-traditional research methods (e.g. mathematical, sociological, expert), as well as analyticity, constructiveness and depth of one's thinking ${ }^{10}$.

It was taken into account that business efficiency is manifested in such properties of the expert as one's abilities to concentrate in teamwork especially on the gender differences conflict problem-solving, resist conformism, take into one's account only some information on the investigation subject and correct estimation (based on the results of the anonymous survey). We evaluated the experts' objectivity according to the results of their previous expert reviews. The requirements for the experts were the following: 1) a scientific degree;

${ }^{9}$ Volobuieva O. F. (2018). Volobuieva O. F. (2018). Leader and leadership of the security sector: gender aspect. Visnyk of the Taras Shevchenko National University of Kyiv Military-Special sciences, 1(38). [in Ukrainian].

${ }^{10}$ Cherepanov, V. (1989) Expert Assessment in Pedagogical research. Moscow : Pedagogics Publ. [in Russian] 
2) academic rank; 3) experience in a management position; 4) participation in the work of expert groups on related topics; 5) the attitude towards the up-to-date research methods including mathematical and expert ones. Taking into our consideration the recommendations of the expert assessment ${ }^{11}$. 6) we used the mutual recommendation methods, self-assessment, reasoning and questionnaire data to assess the competence of the experts. The mutual recommendations coefficient has been calculated by the following formula:

$$
K_{j}^{\beta 3}=\frac{x_{j}}{\sum_{j=1}^{m} x_{j}} \text { where }
$$

$x_{j}=\sum_{i=1}^{m} x_{i j}-$ the individual rating of the expert candidate; $x_{i j}-$ the number of choices; $m$ - the number of expert candidates.

According to the of mutual recommendations method, the group of 50 persons (including 17 females and 33 males ones) - the leaders of the structural units of the NASBSU with some leadership experience were selected among the candidates for the experts.

These were the very leaders who are responsible: 1) for organizing, supporting and controlling the service organization in subordinate units and moreover providing the moral and psychological support for the professional activity of subordinate personnel and also 2) for the organizational renewal for its development. In this connection for us was absolutely important the fact that data collection serves the important and useful functions in an organization development ${ }^{12}$.

We conducted the survey of the leaders of the structural units on the understanding and evaluating the importance of the leader's ability to create the gender-sensitive environment in their subordinate

${ }^{11}$ Cherepanov, V. (1989) Expert Assessment in Pedagogical research. Moscow: Pedagogics Publ. [In Russian]

${ }_{12}$ Lippitt, Gordon L. (1982). Organization renewal. A Holistic Approach to Organization Development, Second Edition. Printice - Hall, Inc., Englewood Cliffs, New Jersey, the USA. 
structural units as the essential part of their professional competence (i.e. the abilities to carry out their professional duties up-to-the level.

The obtained experts' evaluation results of the survey were used for the initial analysis. At the same time it was taken into our account the fact that with the help of survey it is possible to collect the quantitatively important material, which makes it possible to consider the received answers to be rather probable. The questionnaire (worked out by us), which has been used to reveal the experts views about the research area is shown below (table 1).

Table 1

\section{Questionnaire "Leader's Ability to Create Gender-Sensitive Environment as Part of Professional Competence"}

\section{Dear colleagues!}

Please answer the following questions:

\begin{tabular}{|c|c|}
\hline № & Questions \\
\hline 1 & 2 \\
\hline 1 & What is your scientific degree (if you have any)? \\
\hline 2 & What is your academic rank (if you have any)? \\
\hline 3 & $\begin{array}{l}\text { What is your experience of the leaders' position (please, mention the } \\
\text { number of the years)? }\end{array}$ \\
\hline 4 & $\begin{array}{l}\text { Could you explain the meanings of the terms: } \\
\text { 1) "gender" and 2) "sex", please. }\end{array}$ \\
\hline 5 & Please, reveal the meaning of the term "gender sensitive". \\
\hline 6 & $\begin{array}{l}\text { Please, explain the meaning of the term "responsibility of the } \\
\text { manager for the organizational (institutional) culture of the gender- } \\
\text { sensitive environment". }\end{array}$ \\
\hline 7 & $\begin{array}{l}\text { Do you think it is sufficient to have only the general abilities for } \\
\text { effective management of the unit? Is it obligatory for a leader to have } \\
\text { the specific abilities and knowledge in order to create gender- } \\
\text { sensitive environment? Why? }\end{array}$ \\
\hline 8 & $\begin{array}{l}\text { Are gender stereotypes and discrimination common in the unit you } \\
\text { manage? }\end{array}$ \\
\hline 9 & What does the term "leader's professional gender competency" mean? \\
\hline
\end{tabular}


End of Table 1

\begin{tabular}{|c|c|}
\hline 1 & 2 \\
\hline 10 & Is sexual harassment a common practice in the unit? (Yes / No)? \\
\hline 11 & $\begin{array}{l}\text { What personal characteristics are the indexes of the leader's ability to } \\
\text { create the gender-sensitive environment in the security and defense } \\
\text { sector? }\end{array}$ \\
\hline 12 & $\begin{array}{l}\text { Do you have any responsibility, as a leader, for gender equality in the } \\
\text { unit? }\end{array}$ \\
\hline 13 & $\begin{array}{l}\text { Are there any mutual respectful relationships between female and } \\
\text { male officers in your unit? }\end{array}$ \\
\hline 14 & $\begin{array}{l}\text { Are gender-based inequalities in the workplace (such as the } \\
\text { disrespectful computer screensavers, posters, jokes, no femininities } \\
\text { usage (if you have any) where appropriate) stopped or allowed in } \\
\text { your unit? In what way? Please, give some examples. }\end{array}$ \\
\hline 15 & $\begin{array}{l}\text { Do you think that the ability to create the gender-sensitive } \\
\text { environment is part of the professional competence of the effective } \\
\text { leader? If so, is it innate or can it be during the training and further } \\
\text { service of officers? }\end{array}$ \\
\hline 16 & $\begin{array}{l}\text { Could you describe the effective leader who is able to create the } \\
\text { proper gender-sensitive environment, please? }\end{array}$ \\
\hline 17 & $\begin{array}{l}\text { Please, describe an officer who can never be a successful leader } \\
\text { because of his/her gender stereotypes. }\end{array}$ \\
\hline 18 & $\begin{array}{l}\text { Is there understanding between the male and female personnel in } \\
\text { your unit? }\end{array}$ \\
\hline 19 & $\begin{array}{l}\text { The gender policy is being realized and gender is being integrated } \\
\text { into the educational process effectively at the National Academy of } \\
\text { the State Border Guard Service of Ukraine named after Bohdan } \\
\text { Khmelnitsky. Do all your subordinates know about these facts? } \\
\text { (Yes / No). }\end{array}$ \\
\hline 20 & $\begin{array}{l}\text { What are the differences between the views of women and men on } \\
\text { gender issues in the unit? }\end{array}$ \\
\hline 21 & $\begin{array}{l}\text { What information do the new personnel get about the commitments } \\
\text { to providing gender equality and human rights at the NASBGSU? }\end{array}$ \\
\hline
\end{tabular}

Thank you very much for your answers!

The characteristics of the personnel who participated in the survey are shown below in table 2 . 
Table 2

Characteristics of Personnel Participated in Survey

\begin{tabular}{|l|c|c|c|c|c|c|}
\hline \multicolumn{1}{|c|}{$\begin{array}{c}\text { Characteristics } \\
\text { of the personnel }\end{array}$} & \multicolumn{2}{|c|}{ Female } & \multicolumn{2}{c|}{ Male } & \multicolumn{2}{c|}{ Total } \\
\cline { 2 - 7 } & number & $\%$ & number & \% & number & $\%$ \\
\hline $\begin{array}{l}\text { Personnel with the } \\
\text { rank of Professor }\end{array}$ & 4 & $23,53 \%$ & 3 & $9,09 \%$ & 7 & $14 \%$ \\
\hline $\begin{array}{l}\text { Personnel with the } \\
\text { rank of Assistant } \\
\text { Professor }\end{array}$ & 10 & $58,82 \%$ & 6 & $18,18 \%$ & 16 & $32 \%$ \\
\hline $\begin{array}{l}\text { Personnel with no } \\
\text { academic rank }\end{array}$ & 3 & $17,65 \%$ & 24 & $72,73 \%$ & 27 & $54 \%$ \\
\hline $\begin{array}{l}\text { Personnel with Doctor } \\
\text { of Sciences Degree }\end{array}$ & 5 & $29,41 \%$ & 4 & $12,12 \%$ & 9 & $18 \%$ \\
\hline $\begin{array}{l}\text { Personnel with } \\
\text { a PhD degree }\end{array}$ & 11 & $64,71 \%$ & 11 & $33,33 \%$ & 22 & $44 \%$ \\
\hline $\begin{array}{l}\text { Personnel with no } \\
\text { scientific degree }\end{array}$ & 1 & $5,88 \%$ & 18 & $54,55 \%$ & 19 & $38 \%$ \\
\hline $\begin{array}{l}\text { Have more than } \\
\text { 20 years of senior } \\
\text { management } \\
\text { experience }\end{array}$ & 2 & $11,76 \%$ & 4 & $12,12 \%$ & 6 & $12 \%$ \\
\hline $\begin{array}{l}16-20 \text { year experience } \\
\text { in management } \\
\text { positions }\end{array}$ & 3 & $17,65 \%$ & 3 & $9,09 \%$ & 6 & $12 \%$ \\
\hline $\begin{array}{l}11-15 \text { year experience } \\
\text { in management } \\
\text { positions }\end{array}$ & 6 & $35,29 \%$ & 11 & $33,33 \%$ & 17 & $34 \%$ \\
\hline $\begin{array}{l}6-10 \text { year experience } \\
\text { in management } \\
\text { positions }\end{array}$ & 5 & $29,41 \%$ & 10 & $30,30 \%$ & 15 & $30 \%$ \\
\hline $\begin{array}{l}\text { Leadership experience } \\
\text { is less than 5 years }\end{array}$ & 1 & $5,88 \%$ & 5 & $15,15 \%$ & 6 & $12 \%$ \\
\hline
\end{tabular}

\section{Survey analysis results}

The analysis results of the survey testify about the fact that all the respondents do not find any gender stereotypes (the answers to the Question 8) and sexual harassment (the answers to the Question 10) to be a common practice in their units. 
The respondents' answers to the questions 13, 15, 18 and 19 are the positive ones as for:

- the necessity of the respectful relationships between the female and male officers in the units (question 13);

- the ability to create the gender-sensitive environment (which is considered to be part of the effective leader's professional competence and which is not innate and that is to be formed in the process of special gender-aimed training (question15);

- understanding between female and male personnel in the unit (question 18);

Concerning the realization of the gender policy at the NASBGSU and gender mainstreaming into the educational process (question 19) the questioned leaders have also given the positive answer.

As for:

- the leader's responsibility for gender equality in the unit (question12)49 respondents answered briefly:" Yes." and one person has given the following reply "Yes, I as the leader of the military unit adhere to the principle of equality. It is my duty";

- the gender-based inequalities in the workplace(question 14), the answers with the numbers of respondents are the following:

- "women should not be in the army"- 2 answers of the male leaders- $4 \%$;

- "the cases of gender inequality happened at the workplace" 48 answers (16 answers of female and 28 of male leaders);

- revealing the meaning of the terms 'gender' and 'sex' (question 4), the majority of the respondents (total number - 44, including 16 female and 28 male officers have given the same answer, namely they find: "gender" to be a social concept which defines the traits and behaviors that are typical of women and men in a particular society and 2) sex to be a biological concept, the state of being male or female.

We would like to point out that speaking about the respondents answers to question 5 which deals with the leaders' understanding of the term "gender-sensitive environment" the opinions of the leaders are the following:

- 11 respondents $(22 \%)$ have not defined the term correctly;

- 39 leaders find the term to be:

1) the environment where the gender-based conflicts can occur 16 people $(32 \%)$; 
2) the environment where women are the equal partners with men in any field of professional activity -13 people $(26 \%)$;

3 ) the environment where the colleagues understand, respect and support each other and help everyone to realize their abilities and make the career -6 people (12\%);

4) the environment where there are no gender stereotypes, and which is sensitive to the relevant changes and promotes effective activity -4 people $(8 \%)$.

As for the explanation of the meaning of the term "responsibility of the manager for the organizational (institutional, corporative) culture of the gender-sensitive environment" such answers have been given to the question as:

- cultivating by the leader of the unit the rights of both male and female representatives at their workplace -12 persons $(24 \%)$;

- the leader of the unit regularly organizes round table discussions on gender agenda within of the gender program which is aimed at supporting gender balance in the unit - 12 people (24\%);

- the head of the unit is responsible for promoting gender policy -9 people (18\%);

- obligatory maintaining gender balance -8 people $(16 \%)$;

leader's personal responsibility for the proper monitoring and maintaining the gender-sensitive environment -9 persons $(18 \%)$.

The respondents' answers to question 7 which touches upon the aspect of the importance of the general and specific abilities for effective management, particularly for creating the gender-sensitive environment, are the following:

- 29 people $(58 \%)$ have found the specific abilities to be obligatory for proper management and creating the positive genderbased atmosphere;

- 12 people (24\%) have considered the specific ability to be essential because they are more related to behaviors in the unit (as a group). (The specific abilities include not only those which may be reflected in the general ability, but also special skills and knowledge ${ }^{13}$;

${ }^{13}$ Shaw E. Marvin. (1976). Group Dynamics. The Psychology of Small Group. The USA : McGraw-Hill. 
- 9 people (18\%) have answered that it is not enough to possess only the general abilities, to their opinion the very specific abilities and essential knowledge are an integral part of the effective leader proficiency.

As for the meaning of the term "leader's professional gender competence" the answers to the question 9are the following:

- everything related to the professional activity of a manager 21 persons $(42 \%)$;

- combination of professionalism with gender competence 14 persons $(28 \%)$;

- effective competence of the manager in the system of intergender relations -4 persons $(8 \%)$;

- ability to prevent gender discrimination in the unit -3 persons $(6 \%)$;

- tactful and correct attitude to gender differences -3 persons $(6 \%)$

- acquired knowledge and abilities to provide the gendersensitive environment -3 persons $(6 \%)$;

- knowledge of the traits of female and male behavior characteristic -3 persons $(6 \%)$.

While answering question 11 the following typical personal characteristics (as the index of the leader's ability to create the gendersensitive environment in the security and defense sector) have been mentioned:

1) awareness of understanding the importance the gender equality issues, tolerance, flexibility, respect for subordinates regardless of their gender;

2) the ability to eliminate the gender hierarchy between female and male representatives;

3) diagnostic ability, flexibility, correctness, peaceful attitude;

4) the ability to notice and adequately assess situations of gender inequality, avoid gender discriminatory practices;

5) the team-work ability, empathy, professional competence;

6) management responsibility and the ability to see personality in subordinate personnel.

As for question 16 according to the respondents' opinions the principle traits of a "commander who is able to create the gendersensitive environment" are the following: 
- equal attitude towards female and male representatives 7 people $(14 \%)$

- a professionally competent leader who is capable of creating a gender-sensitive environment on the basis of politeness and respect 43 people (86\%).While answering question 17 (question on the description of the officer who can never be a successful leader because of gender stereotypes the majority of respondents (42 leaders $84 \%$ )have expressed their opinions in such a way:

They find the direct connection of the existence of gender stereotypes with the leader's management strategy for effective group dynamics which depends on the leader1s gender professional competence.

8 respondents (16\%) expressed such opinions as:

- a hating officer violating the human rights of the representatives;

- an officer who cannot prevent and resolve gender issues and conflicts;

- a supporter of discrimination, supports gender inequality, seeks authority, distrust to women in their tasks performance;

- cheeky, sloppy, irreconcilable to the opposite gender;

- not ready for self-improvement;

- an officer who does not respect the opinion of a person of the other gender;

- a gender biased officer believes that gender stereotypes are the traditional ones and does not want to understand the importance of the gender tolerance and leader's responsibility to create the gendersensitive environment.

What information do the new personnel get about the commitments to providing gender quality and human rights at the NASBGSU?

As for question 21 - the question on informing the new personnel about gender equality of the NASBGSU the answers have testified that they are informed about:

- the Regulations on the Subdivision of the National Academy of the State Border Guard Service of Ukraine , particularly, unit III "On Gender Policy" - 3 persons (6\%);

- special instruction on prevention of gender discrimination 2 persons $(4 \%)$; 
$(6 \%)$;

- on providing the gender sensitive environment - 3 persons

- some information on gender integration into the educational process -4 persons $(8 \%)$;

- on the implementation of gender equality in security and defense sector -38 persons $(76 \%)$.

\section{CONCLUSION}

1. Having analyzed the results of the survey we have come to the following conclusion:

2. Not all the interviewed officers have given the correct definition of the terms 'gender-sensitive environment' and 'leader's professional gender competence'. This fact testifies about the fact that at the level of their awareness they do not understand, as any up-todate leader has to, the very nature of the proper created environment for the effective professional activity.

3. There is some concern at the level of male executives' awareness of the proper perception of gender roles and gender as a phenomenon in the military environment, where gender stereotypes are traced, which negatively affects the moral and psychological climate in the units and as a consequence the effectiveness of the professional performance.

4. Leaders at all levels need to be educated in gender specifics in order to form the appropriate level of their gender competence the proper level of which will guarantee the essential level of creating the gender-sensitive environment in the units.

5. In order to form the necessary level of the leaders' gender professional competence itself vital importance to involve leaders into the special gender training.

6. The effective personnel policy and successful management play an important role in making changes to the organizational culture of the unit in the conditions of the higher educational establishment.

In this context we would like to point out that as for the essence of the concept of the organizational culture (institutional culture, corporative culture) authors A. Raj, R. Stuart, and D. Kelleher, give the following definition of the term "institutional culture" as a set of 
values, history, and ways of doing things that shape the unspecified "rules of the game" in an institution".

7. The very organizational (institutional, corporative) culture can be a powerful ally in ensuring gender equality in the most valuable part of an institution's activity, or it can block progress on gender issues making it difficult for women to be real personality and develop oneself in harmony with other female colleagues.

8. While investigating the results of the survey we have noticed the tendency in the respondents' answers that it is important for them to increase the level of their awareness as for the importance of taking into their accounts the fact that gender perspective is absolutely important for the development of the unit as a group and rise in effectiveness of the group organization and management of female and male group members' activities is aimed to improving human resources (HR) management. Within any group there is a number of recognized roles that are generally accepted as relevant for intragroup interaction and activity. We are interested not only in the regularities of collaborative female and male individuals in the framework of group processes, but also in the personality of separate group member and the peculiarities of the very organization of his/her individual activity within the framework of social group as organized system ${ }^{15}$ in the military environment.

9. In the survey of the leaders it has been found that there do some significant not understand the peculiarities of the very organizational culture as the process of the very change process of the whole unit as the organization development which attempts to integrate female and male individual needs for growth and development with organizational goals and objectives in order to make a more effective organization ${ }^{16}$.

${ }^{14}$ Raj, A, Stuart, R. and Kelleher, D. What is gender at Work's Approach to Gender Equality and Institutional. Retrieved from http://www.genderatwork.org/ sites/genderatwork.org/files/resources/Gender_at_Works_Approach.pdf.

${ }^{15}$ Volobuieva Olena. (2018). Social group as organized system: psychological aspect. Mukachevo-Chenstokhova: RVVMDU; ta Akademiia im. Yana Dluhosha. 2(25). [in Ukrainian]

${ }^{16}$ Lippitt, Gordon L. (1982). Organization renewal. A Holistic Approach to Organization Development, Second Edition. Printice - Hall, Inc., Englewood Cliffs, New Jersey, the USA. 
That is why it is essential to pay attention to the role of consciousness in the system of professional training the whole personnel.

10. Moreover it is essential to study the problems of female and male individuals interaction in the system "conscious leader of the unit - conscious subordinate".

11. Taking into consideration the fact that conscious is the highest level of activity relation on the grounds of the particular values of the concrete military unit (as a group) member it is absolutely important to provide conscious attitude of the whole personnel towards the very gender process which determines his/her effective cognitive activity, maximum creative activity and independence. That is why the process of gender training is to be organized in such a way in order to promote conscious active interaction between both the teacher and the subject of the training process.

12. In order to create the proper gender sensitive environment in the unit the leader has to be good at group dynamics and specific peculiarities of gaining some gender knowledge by the whole personnel of the group on the proper socio-psychological provision basis.

13. For effective forming of the essential level of gender professional competence it is necessary to use problem-solving situations on the basis of socio-psychological determinants of group influence. The usage of such situations gives the opportunity to form some psychological operations and their complexes through the interaction of various kinds of gender based professional activities on the basis of taking into one's consideration the gender differences within the group structure.

14. Taking into account the fact that leader is the person who is in the focus of group behavior and leadership is the process or act of influencing. A unit is assigned formal power to hire, discharge, reward, and penalize the individuals in order to mold their behavior in the pattern of the organization's objectives on the grounds of the organizational culture in the military environment.

15. While using the particular methods of gender problem solving it is of vital importance for the leader to remember about the "familyfriendly" policy in the conditions of the higher military educational establishment. The leader of the unit has to be good at understanding 
the organizational culture of gender-sensitive environment, its mission and basic aspects of relationship system, which should be taught purposefully, systematically and comprehensively. In this context, the recommendations of Women's Information and Advisory Center deserve attention ${ }^{17}$.

16. In the context of investigating the leader's ability to form the favourable gender-sensitive environment for the whole personnel, itis extremely important for us roundest and the sense of the term "leader's behaviour culture" is a set of formed, socially significant personality traits, actions in based on the norms of morality, ethics, aesthetics and culture $^{18}$.

For a leader of any rank, itis extremely important to have a high level of behaviour culture, the proper level of which ensures the following moral bases as the essentials of the leader's gender professional competence as: 1) fulfilment of their duties sand moral requirements, demanding of one self and others, active and proactive actions, respect for rights and freedoms of both female and male personnel; assistance and support of subordinates, including in realization of personal capacities and abilities on gender perspectives basis; 2) responsibility - a duty to help or take care of the personnel because of the position ${ }^{19}$; respect for human dignity; respect for another person as a unique personality, etc.

17. Effective personnel policy and successful management play an important role in making changes to the organizational culture of the unit in the conditions of the higher military educational establishment. It is urgent for a manager of an educational institution to have a proper understanding of organizational culture, its mission and the basic aspects of its system of relationship. In this connection we would like to point out that Angela Workman-Stark, PHD, associated

17 Suslova, O. (2019). Systemic Reforms: The Principle of Equal Rights and Opportunities for Women and Men and Anti-Discrimination Approach. Kyiv. [in Ukrainian]

18 Education. Encyclopedia Academy of Pedagogical Science of Ukraine / ed. V. Kremen' (2008) Yurinkom Inter. Kyiv. [In Ukrainian]

19 Hornby A. S. (2005). Oxford Advanced Learner's Dictionary of Current English, Oxford University Press, the Seventh Edition. 
professor and program director of Faculty of Business at Athabasca University, Canada, having a 24-year career in the federal law enforcement in the academic article "Creating Inclusive Teams. Six Essential Steps for leaders" attracts our attention to the fact that it is essential for a leader to find the balance approach, which gives the opportunity to integrate diverse female and male individuals into the workplace while at the same time respecting and harnessing individual differences ${ }^{20}$.

18. The comprehensive integration of gender equality dimensions into the education sector reforming processes, which is taking place in the defense, and security sector of Ukraine is critical to meet the standards of representative and rights-respecting needs of women. That is why nowadays it is essential to change the way every leader is thinking about the gender phenomenon (which is not fully understood in the Ukrainian society).

19. The results of the investigation have testified the necessity of the rise in the level of the leaders' gender organizational abilities at all the levels of professionalization.

The size of the article does not give us the opportunity to reveal all the results of our investigation. The further direction sin the process of investigation of the problem of the leaders' gender organizational abilities are: 1) studying the role of the leader's consciousness in the process of creating inclusive teams; 2) working out the Program of the forming gender competence of the organizational abilities of the border guard officers, students and cadets of the NASBGS of Ukraine.

\section{SUMMARY}

The article deals with revealing the results of the investigation of leader's ability to create gender-sensitive environment. We consider gender competence to be the essential part of the leader's professional competence, i.e. the ability to perform the professional duties up to the level. We have worked out the questionnaire on the leader's ability to create the gender-sensitive environment within

${ }^{20}$ Workman-Stark Angela. Creating Inclusive Teams. Six Essential Steps for leaders. BEP Business Expert Press. Retrieved from https:www.businessexpertpress.com. 
the framework of organizational culture in the conditions of the higher military educational establishment. The results of the investigation testify that it is of vital importance to teach leaders gender in order to develop their abilities to create gender-sensitive environment in the units effectively. The gender knowledge will give a leader the opportunity to regulate group processes and influence upon group dynamics for its effective organization and development.

The results of the investigation have testified:

1) the necessity of the rise in the level of the leaders' gender organizational abilities at all the levels of professionalization;

2) the importance of providing the conscious attitude of leader towards gender training as the essential part of the professional development in order to have the proper level of professional gender competence.

3) the results of the investigation will give us the opportunity to study the peculiarities of the leader's consciousness role in the process of professional training.

The size of the article does not give us the opportunity to reveal all the results of our investigation. The further directions of the studying the problem of the leaders 'gender organizational abilities are:

1) studying the role of the leader's consciousness in the process of creating inclusive teams;

2) working out the Program of forming gender competence of the organizational abilities of the border guard officers, students and cadets of the National Academy of the State Border Guard Service of Ukraine named after Bohdan Khmelnitskyi.

\section{REFERENCES}

1. Beijing Declaration and Platform for Action. https://www.un.org/en/events/pastevents/pdfs/Beijing_Declaration_and _Platform_for_Action.pdf.

2. Cherepanov, V. (1989). Expert Assessment in Pedagogical research. Moscow: Pedagogics Publ. [in Russian].

3. Ernst Stephanie (2013). Theorizing and Practizing Organizational Culture and Diversity. A Case Study // Anno III, Numero 6 / Dicembre. Retrieved from https://www.accaglobal.com/ 
content/dam/acca/global/PDF-technical/human-capital/pol-tp-tbcfdmdiversity-management.pdf.

4. Gender and Security. (2012). Training Manual. UN Women, DCAF.

5. Hornby A. S. (2005). Oxford Advanced Learner's Dictionary of Current English, Oxford University Press, the Seventh Edition.

6. Macarie Felicia Cornelia, Hinţea Călin, Mora Cristina. Gender and leadership the impact on organizational culture of public institutions. Transylvanian Review of Administrative Sciences, No. 32 E/2011, pp. 146-156. p. 147) Retrieved from https://www.research gate.net/publication/292452492_Gender_and_Leadership_The_ Impact_of_Organizational_Culture_of_Public_Institutions.

7. Women, Peace and Security (2011). Geneva.

8. Raj, A, Stuart, R. and Kelleher, D. What is gender at Work's Approach to Gender Equality and Institutional. Retrieved from http://www.genderatwork.org/sites/genderatwork.org/files/resources/ Gender_at_Works_Approach.pdf.

9. Sustainable Development Goals by 2030. Retrieved from https://www.un.org/sustainabledevelopment/blog/tag/security-council. Agenda 2030.pdf.

10. Volobuieva O. F. (2018). Leader and leadership of the security sector: gender aspect. Visnyk of the Taras Shevchenko National University of Kyiv Military-Special sciences, 1(38). [in Ukrainian].

11. Volobuieva Olena. (2018). Social group as organized system: psychological aspect. Mizhnarodnyi naukovyi zhurnal "Osvita i nauka": RVVMDU; ta Akademiiaim. Yana Dluhosha. 2(25). [in Ukrainian]

12. Lippitt, Gordon L. (1982). Organization renewal. A Holistic Approach to Organization Development, Second Edition. Printice Hall, Inc., Englewood Cliffs, New Jersey, the USA.

13. Shaw Marvin E. (1976). Group Dynamics. The Psychology of Small Group Behavior, McGraw-Hill Book Company, the USA.

14. The significance of gender equality and women's empowerment for the security sector reform. OECD DAC Handbook on security system reform. Section 15: Integrating Gender Awareness and Equality, OECD, 2009 Edition. http://www.oecd-ilibrary.org. 
15. Systemic Reforms (2019).The Principle of Equal Rights and Opportunities for Women and Men and Anti-Discrimination Approach. Kyiv. [In Ukrainian].

16. Education. Encyclopedia Academy of Pedagogical Science of Ukraine / ed. V. Kremen (2008). Yurinkom Inter. Kyiv. [In Ukrainian].

\section{Information about the author:}

Olena Volobuieva

Doctor of Sciences in Psychology, Professor, Academic Research Deputy Rector,

National Academy of the State Border Guard Service of Ukraine named after Bohdan Khmelnytskyi 46, Shevchenko str., Khmelnytskyi, 29003, Ukraine ORCID ID: orcid.org/0000-0003-4010-6398 E-mail: helen_volobueva@ukr.net 